\title{
Southernmost records of Pachyramphus marginatus (Passeriformes: Tityridae) and first observation for Santa Catarina State, southern Brazil
}

\author{
Fernando Bittencourt de Farias ${ }^{1 *}$ \\ Guilherme Willrich ${ }^{2}$ \\ Guilherme Renzo Rocha Brito ${ }^{1}$ \\ ${ }^{1}$ Universidade Federal de Santa Catarina, Departamento de Ecologia e Zoologia \\ Laboratório de Ornitologia e Bioacústica Catarinense \\ Campus Universitário, s/n, CEP 88.040-970, Florianópolis - SC, Brasil \\ ${ }^{2}$ Caipora Cooperativa para Conservação da Natureza \\ Avenida Desembargador Vítor Lima, 260/908, CEP 88.040-400, Florianópolis - SC, Brasil \\ * Autor para correspondência \\ fernando-farias@hotmail.com
}

Submetido em 16/03/2021

Aceito para publicação em 02/08/2021

\section{Resumo}

Registro mais ao sul de Pachyramphus marginatus (Passeriformes: Tityridae) e primeiro registro para o estado de Santa Catarina, sul do Brasil. O caneleiro-bordado possui duas subespécies isoladas geograficamente, sendo que a subespécie da Mata Atlântica é distribuída de Pernambuco ao Paraná. Apresentamos aqui a primeira observação da espécie no estado de Santa Catarina, sul do Brasil. Em 12 de novembro de 2019, um macho adulto de Pachyramphus marginatus foi observado no município de São Francisco do Sul, litoral nordeste do estado de Santa Catarina, durante um inventário para a criação de uma unidade de conservação. A espécie também foi observada em outras três ocasiões na mesma localidade. Esses registros são os primeiros conhecidos para Santa Catarina estendendo-se por cerca de $40 \mathrm{~km}$ ao sul de sua área de distribuição conhecida. Também discutimos algumas explicações para os registros apresentados.

Palavras-chave: Caneleiro-bordado; Distribuição geográfica; Extensão de alcance; Mata Atlântica

\section{Abstract}

The Black-capped Becard (Pachyramphus marginatus) has two geographically isolated subspecies, including the Atlantic Forest subspecies that is distributed from Pernambuco State to Paraná State. Here we report the first observation of the species in Santa Catarina State, southern Brazil. On 12 November 2019 an adult male of $P$. marginatus was observed in the municipality of São Francisco do Sul, on the northeastern coast of Santa Catarina, during an inventory for the creation of a protected area. The species was also observed on three other occasions in the same locality. These are the first known records for Santa Catarina and extend the known distribution range of this species $40 \mathrm{~km}$ southward. We also discuss some explanations for the records.

Key words: Atlantic Forest; Black-capped Becard; Geographic distribution; Range extension 
The Black-capped Becard, Pachyramphus marginatus (Lichtenstein, 1823) (Passeriformes: Tityridae), is a neotropical bird species with two geographically isolated subspecies, one in the Amazon region ( $P$. m. nanus) and another in the Atlantic Forest (P. m. marginatus) (SICK, 1997; BIRDLIFE INTERNATIONAL, 2020; MOBLEY 2020). Both subspecies are currently evaluated as Least Concern (BIRDLIFE INTERNATIONAL, 2020). According to BirdLife International (2020), the Atlantic Forest subspecies is distributed from Pernambuco State to São Paulo State (Figure 1). However, the species has been recorded further south in the last decades. Ricardo Parrini (apud SICK, 1997, p. 632) appears to be the first person to mention the occurrence of the species on the coast of Paraná State (southern Brazil). He observed the species on 22 October 1993 at Caminho do Itupeva, in the municipality of Morretes, and in the municipality of Guaratuba in 1998 (R. Parrini, personal communication). The first documented occurrence of the species for Paraná State is attributed to Vitor de Q. Piacentini, who observed it in June and September 2005 at the Salto
Morato Private Natural Heritage Reserve (RPPN Salto Morato), in the municipality of Guaraqueçaba, and put voice recordings on the Xeno-canto website (xeno-canto. org; vouchers XC76782, XC76783 and XC76784). Two additional observations of the species were made in RPPN Salto Morato in October 2011 (HORI, 2011) and recordings of these are on the WikiAves website (wikiaves.com.br; vouchers WA479543, WA488573). After these initial observations, several records were made by ornithologists and birdwatchers in Paraná State, including in the municipalities of Guaraqueçaba, Antonina, Morretes and Guaratuba (Figure 1). All these records are available in online databases, such as WikiAves and eBird (ebird.org), but none have been formally published. To date, the observation by Carlos Gussoni in Guaratuba Bay, in the municipality of Guaratuba (GUSSONI, 2013), is recognized as the southernmost occurrence of the species population in the Atlantic Forest. Here, we present new observations of $P$. marginatus that extend its distribution southward and, for the first time, document its presence in Santa Catarina State, southern Brazil.

FIGURE 1: Southernmost records of Pachyramphus marginatus (Aves, Tityridae) in the Atlantic Forest. The species distribution according to BirdLife International (2020) is highlighted in blue. Red star corresponds to the observations in the Saí district (26²'01.9'S, 48 41'51.8'W), in the municipality of São Francisco do Sul, Santa Catarina State. Green circles represent the municipalities in Paraná State where the species has already been observed: 1) Guaraqueçaba; 2) Antonina; 3) Morretes; and 4) Guaratuba. Brazilian states: SP - São Paulo; PR - Paraná; SC - Santa Catarina.

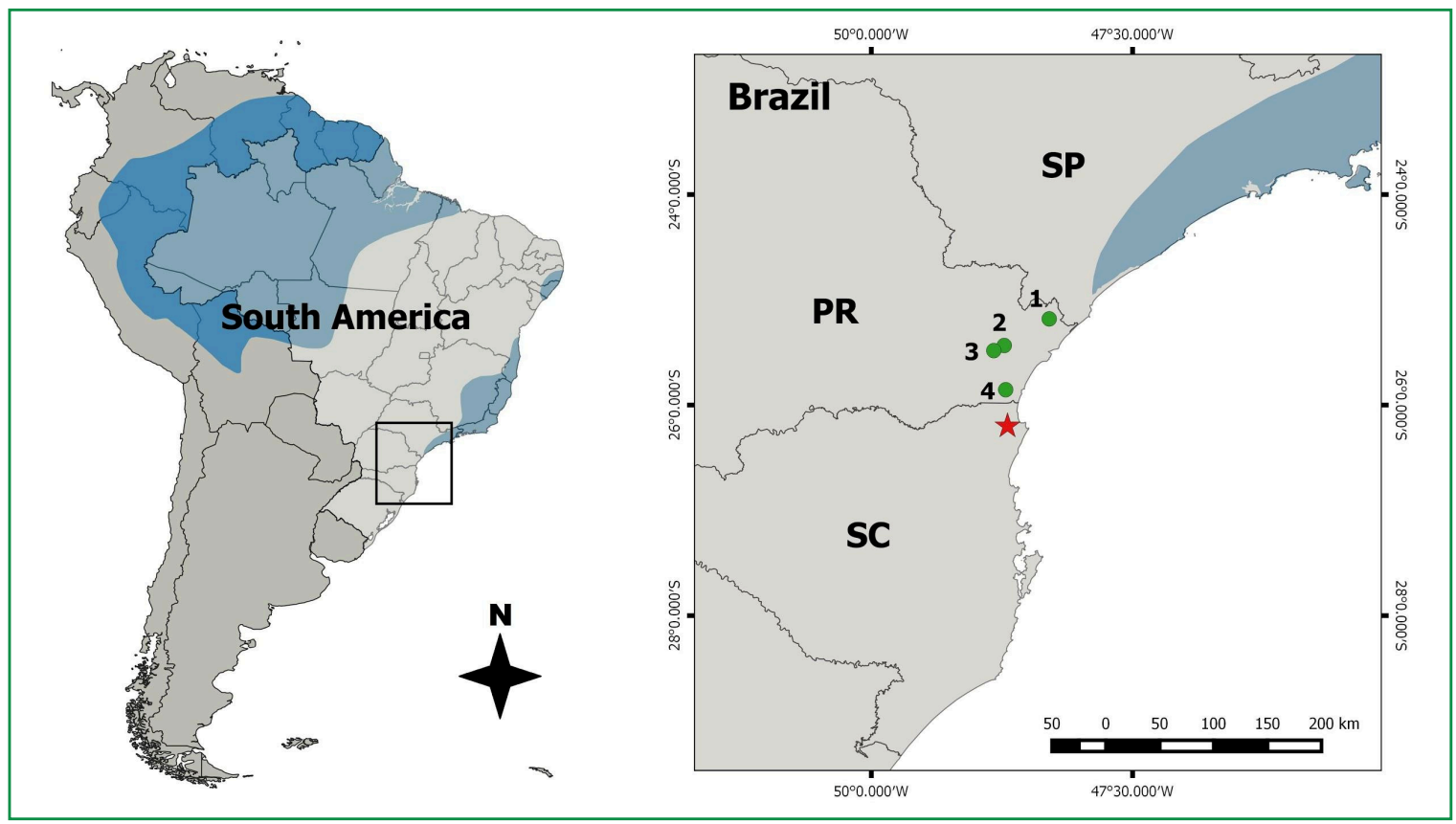


On 12 November 2019 an individual of $P$. marginatus was heard by FBF on a dirt road that crossed a second-growth forest area in the Saí district (Vila da Glória) (26¹2'01.9”'S, 4841'51.8”W; approximately $120 \mathrm{~m}$ a.s.1., Figure 1), in the continental portion of the municipality of São Francisco do Sul, on the northeastern coast of Santa Catarina State. The individual, an adult male, was attracted with playback, voice recorded and photographed (Figure 2). The species was found in the same locality for three consecutive days, and only a single male was observed on all occasions. Another observation of the species was made by FBF and GW in the same place between 15 and 18 January 2020 and, at this time, a female was observed together with a male; the female was not photographed at the time, but some other birdwatchers documented it after the discovery (WikiAves.com.br: WA4217064, WA4096098 and WA4064267). The couple was again observed on

FIGURE 2: Adult male Black-capped Becard (Pachyramphus marginatus) photographed (A) and voice recorded (B) on 12 November 2019 in the Saí district, in the municipality of São Francisco do Sul, Santa Catarina State, southern Brazil. Vouchers: photograph (WA3581245 - Farias (2019a) / sound recording (WA3591225 - Farias (2019b).

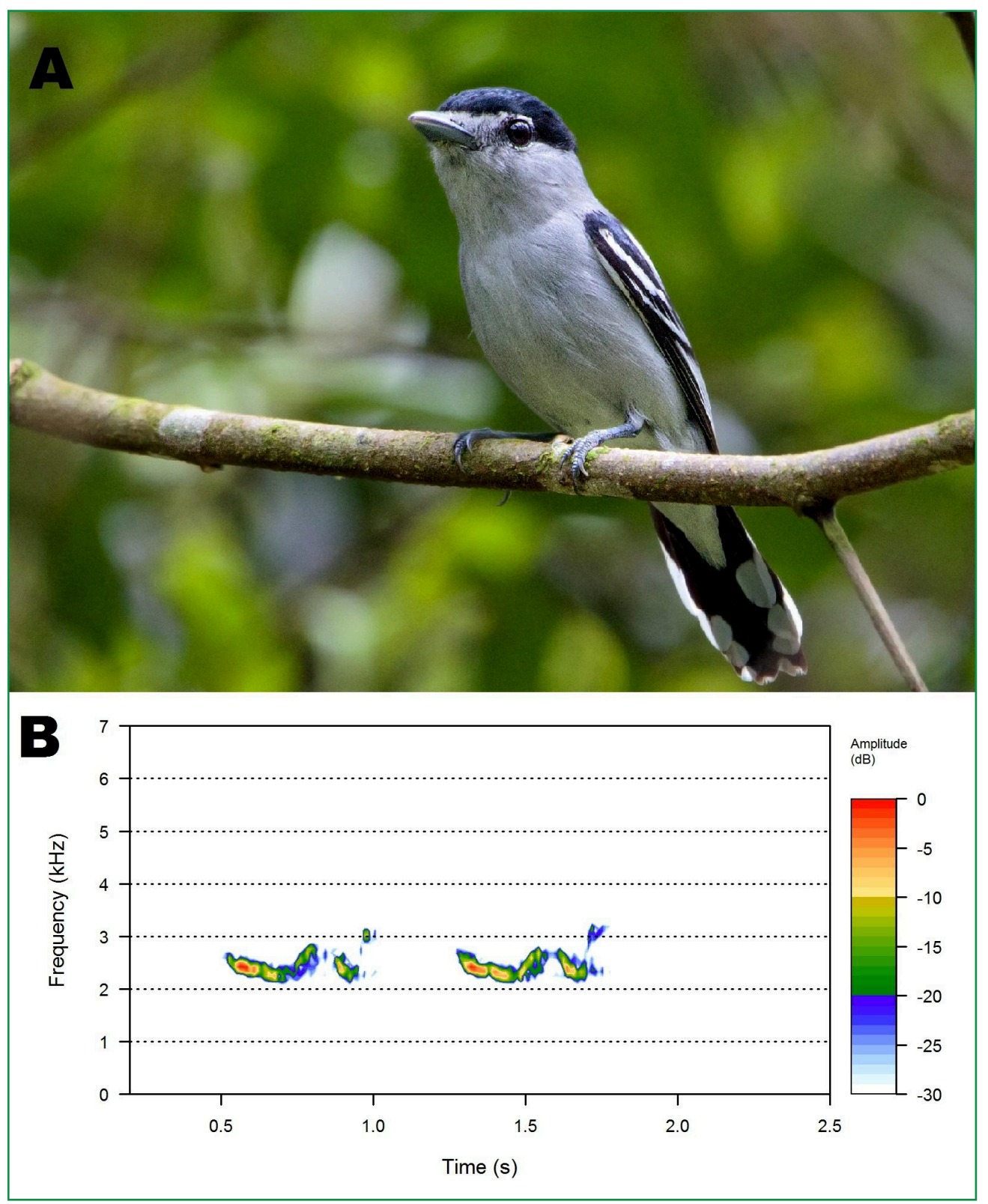


11 February 2020 during a bird trip, and the male was recorded alone on 30 July 2020. The field survey was related to a bird inventory carried out to help create a protected area in the Saí district. Although we looked for the species in other places in the district (e.g., by using playback), to date the species has only been found in the same locality.

These are the first records for Santa Catarina State and the southernmost records for the species. They are approximately $160 \mathrm{~km}$ south of the species distribution limit cited by Birdlife International (2020) and $40 \mathrm{~km}$ from the closest record in Paraná State (i.e., Guaratuba). Moreover, since the species does not migrate like other species of Pachyramphus (SOMENZARI et al., 2018), the present observations made over nine months during both breeding (spring-summer) and non-breeding (autumn-winter) seasons strongly suggest that the couple is settled in the locality.

Several hypotheses can be suggested to explain these records. First, the recent increase in the number of ornithologists and birdwatchers in Santa Catarina State could have increased the probability of detecting the species. However, a high number of ornithological studies $(\mathrm{n}=50)$ have already been conducted on the northeastern coast of the state, in which 474 bird species were recorded (GROSE et al., 2019). Moreover, several ornithologists had already explored this region looking for rare species, such as Kaempfer's Tody-Tyrant (Hemitriccus kaempferi) and others (e.g., BARNETT et al., 2000; NAKA et al., 2000). The region is also home to the Volta Velha Private Reserve, a place that has been highly visited by birdwatchers for at least the last two decades. Therefore, the hypothesis of a recent increase in the number of observers is weakly supported considering the high number of researchers that have conducted studies in the region.

Another possible explanation is the distribution of the species recently expanded southward. Factors that drive shifts in species distributions could be related to, for example, changes in land use or abiotic conditions (e.g., climatic) that allow the establishment of a species in previously unsuitable areas (PECL et al., 2017; GUO et al., 2018). It is known that species distributions are changing worldwide due to climate change and that each species responds at different rates (PECL et al., 2017). Permesan and Yohe (2003), for example, indicated an average poleward range shift of $6.1 \mathrm{~km}$ per decade in a global meta-analysis including 99 bird species, butterflies and plants. This rate would be higher for P. marginatus, considering the first observation in the municipality of Guaratuba in $1998(40-50 \mathrm{~km})$. However, a shift in the distribution range of $P$. marginatus is, for now, merely speculative and needs to be more thoroughly investigated to increase what is known about the species in Santa Catarina State (including abundance data). Since the coastal region of PR and northern SC seems to be the edge of occurrence for this species, it is possible that the species was already present in the area but in very low abundance. This is because species tend to be less abundant at their distribution limits due to limiting environmental variables in these locations, as seen in some plant species (CUMMING, 2002; ARUNDEL, 2005; ANGERT, 2009). Thus, a range expansion would possibly increase the population numbers in the former edges of the distribution of a species.

Although several factors suggest that the species is indeed rare or new in the region, it is important to note some similarities the Black-capped Becard has with other sympatric species that can cause birdwatchers and/or ornithologists to make mistakes in the field. Morphologically, it is very similar to the White-winged Becard (Pachyramphus polychopterus), the latter having darker underparts and lacking light-gray spots on the lores (MOBLEY, 2020), and vocally it is very similar to the Greenish Schiffornis (Schiffornis virescens). Further, these two other species are common in the region. Therefore, we recommend that researchers and birdwatchers pay special attention to these species and their peculiarities when confirming new records of the Black-capped Becard.

\section{Acknowledgements}

We are grateful to Ricardo Parrini and Fernando Costa Straube for the valuable information regarding the occurrence of the species in Paraná State. We also thank the following: BirdLife International for providing the species distribution map; the Prefeitura Municipal de 
São Francisco do Sul for the funding; and the Núcleo de Educação Ambiental (NEAmb/UFSC), Universidade Federal de Santa Catarina (UFSC) and Univille for the great help in the logistics of the fieldwork.

\section{References}

ANGERT, A. L. The niche, limits to species' distributions, and spatiotemporal variation in demography across the elevation ranges of two monkeyflowers. Proceedings of the National Academy of Sciences of the United States of America, Washington, v. 106, n. 2, p. 19693-19698, 2009.

ARUNDEL, S. T. Using spatial models to establish climatic limiters of plant species' distributions. Ecological Modelling, Amsterdam, v. 182, n. 2, p. 159-181, 2005.

BARNETT, J. M.; KIRWAN, G. M.; PEARMAN, M.; NAKA, L. N.; TOBIAS, J. A. Rediscovery and subsequent observations of Kaempfer's Tody-tyrant Hemitriccus kaempferi in Santa Catarina, Brazil, with notes on conservation, life history and plumage. Bird Conservation International, Cambridge, v. 10, n. 4, p. 371-379, 2000.

BIRDLIFE INTERNATIONAL. Species factsheet: Pachyramphus marginatus. 2020. Avaiable in $<$ http://www.birdlife.org $>$.

CUMMING, G. S. Comparing climate and vegetation as limiting factors for species ranges of African ticks. Ecology, New York, v. 83, n. 1, p. 255-268, 2002.

FARIAS, F. B. [WA3581245. Pachyramphus marginatus (Lichtenstein, 1823)]. Wiki Aves - A Enciclopédia das Aves do Brasil. 2019a Available in <http://www.wikiaves.com/3581245>.

FARIAS, F. B. [WA3591225. Pachyramphus marginatus (Lichtenstein, 1823)]. Wiki Aves - A Enciclopédia das Aves do Brasil. 2019b Available in <http://www.wikiaves.com/3591225>.

GROSE, A. V.; FINK, D.; CREMAR, M. J. Revisão bibliométrica de estudos da avifauna no Ecossistema Babitonga, Santa Catarina, Brasil. Revista CEPSUL - Biodiversidade e Conservação Marinha, Itajaí, v. 8, p. 1-21, 2019.

GUO, F.; LENOIR, J.; BONEBRAKE, T. C. Land-use change interacts with climate to determine elevational species redistribution. Nature Communications, London, v. 9, p. 1315, 2018.
GUSSONI, C. O. WA1047749, Pachyramphus marginatus (Lichtenstein, 1823). Wiki Aves - A Enciclopédia das Aves do Brasil. 2013. Avaiable <http://www.wikiaves.com/1047749)>.

HORI. Revisão do inventário avifaunístico e subsídios para a implantação do birdwatching na Reserva Natural Salto Morato (Guaraqueçaba, Paraná). Curitiba: Hori Consultoria Ambiental e Fundação Grupo Boticário de Proteção à Natureza, 2011. 214 p.

MOBLEY, J. Black-capped Becard (Pachyramphus marginatus), version 1.0. In: DEL HOYO, J.; ELLIOTT, A.; SARGATAL, J.; CHRISTIE, D. A.; DE JUANA, E. (Ed.). Birds of the World. Ithaca: Cornell Lab of Ornithology. (Retrieved on September 20th, 2020). 2020.

NAKA, L. N.; BARNETT, J. M.; KIRWAN, G. M.; TOBIAS, J. A.; AZEVEDO, M. A. G. New and noteworthy bird records from Santa Catarina, Brazil. Bulletin of the British Ornithologists' Club, Peterborough, v. 120, n. 4, p. 237-250, 2000.

PECL, G. T.; ARAÚJO, M. B.; BELL, J. D.; BLANCHARD, J.; BONEBRAKE, T. C.; CHEN, I.; CLARK, T. D.; COLWELL, R. K.; DANIELSEN, F.; EVENGARD, B.; FALCONI, L.; FERRIER, S.; FRUSHER, S.; GARCIA, R. A.; GRIFFIS, R. B.; HOBDAY, A. J.; JANION-SCHEEPERS, C.; JARZYNA, M. A.; JENNINGS, S.; LENOIR, J.; LINNETVED, H. I.; MARTIN, V. Y.; MCCORMACK, P. C.; MCDONALD, J.; MITCHELL, N. J.; MUSTOSEN, T.; PANDOLFI, J. M.; PETTORELLI, N.; POPOVA, E.; ROBINSON, S. A.; SCHEFFERS, B. R.; SHAW, J. D.; SORTE, C. J. B.; STRUGNELL, J. M.; SUNDAY, J. M.; TUANMU, M.; VERGÉS, A.; VILLANUEVA, C.; WERNBERG, T.; WAPSTRA, E.; WILIANS, S. E. Biodiversity redistribution under climate change: impacts on ecosystems and human well-being. Science, New York, v. 355, n. 6332, eaai9214, 2017.

PERMESAN, C.; YOHE, G. A globally coherent fingerprint of climate change impacts across natural systems. Nature, London, v. 421, p. 37-42, 2003.

SICK, H. Ornitologia brasileira. Rio de Janeiro: Editora Nova Fronteira, 1997. 862 p.

SOMENZARI, M.; AMARAL, P. P.; CUETO, V. R.; GUARALDO, A. C.; JAHN, A. E.; LIMA, D. M.; Lima, P. C.; LUGARINI, C.; MACHADO, C. G.; MARTINEZ, J.; NASCIMENTO, J. L. X.; PACHECO, J. F.; PALUDO, D.; PRESTES, N. P.; SERAFINI, P. P.; SILVEIRA, L.; F., SOUSA, A. E. B. A.; SOUSA, N. A.; SOUZA, M. A.; TELINO-JÚNIOR, W. R.; WHITNEY, B. M. An overview of migratory birds in Brazil. Papéis Avulsos de Zoologia, São Paulo, v. 58, e20185803, 2018. 